\title{
A Series of Class Acts: Mystifications in Irish Print Media Discourses
}

\author{
Eugene Flanagan \\ Correspondence: Eugene Flanagan, email: eflanaga @eircom.net. \\ Received: January 20, 2017 \\ doi:10.11114/smc.v5i1.2272 \\ Accepted: February 16, 2017 \\ Online Published: March 14, 2017 \\ URL: https://doi.org/10.11114/smc.v5i1.2272
}

\begin{abstract}
In this study, in the context of increasing inequality across the developed economies and beyond, I engage with the related issue of social class. I argue, despite postmodernist claims to the contrary, that social class continues to be a tendency to structure capitalist societies, and a primary determinant of life chances. In so doing, I draw on several strands of international class-based theory and research, and on research in the specifically Irish context. Using an explanatory critique, I highlight the failure of contemporary Irish print media discourses to acknowledge the class-based content of the issues to which they refer, while nevertheless promoting the interests of the dominant parties concerned. In conclusion, among other things, I claim that social class is deeply ingrained in Irish society, but that the sources concerned in the print media are much more likely to mystify than accurately inform their readers on this issue.
\end{abstract}

Keywords: explanatory critique, social class, mystification, print media

\section{Introduction}

According to Winnie Byanyima (2015), executive director of Oxfam International, and co-chair of the World Economic Forum, 2015, burgeoning global inequality between nation states is one of the defining challenges of our time. In addition, Picketty (2014), and Dorling (2014), in their analyses of several contemporary developed economies, highlight the huge inequalities that have arisen since the 1980's within nation states, both in terms of income and wealth. In this study, I will argue that this should come as no surprise to those familiar with the Marxist tradition of critical social analysis and commentary, in which such tendencies are understood as formal, and as following directly from the nature of capitalism itself (Marx, 2016).

Nevertheless, it is claimed in the postmodern present that Marxism has nothing to tell us, that modernity's promises are a cruel illusion, and that the present cannot be improved upon. Indeed, with the eclipse of Marxism, the victory of capitalism, and the demise of the historical ideological struggle between them, that we now live in an era characterised by the 'end of ideology' and the 'end of history' (Fukuyama in Sim, 2000). In this postmodern world, all universalities and essentialisms, including social structures and practices based on common experience and/or interests, such as social class, are replaced with fragments, flexibilities, and contingencies (Wood, 2006). Neither does materiality 'compel' what we say regarding it, our evaluations are not 'forced' by the realities to which we refer, and hence no systematic material foundation for either domination or exploitation exists (Nanda, 2006).

There is, however, resistance to this narrative. As the science of capitalism's contradictions, it is simply incoherent to assert the demise of Marxism in the same breath as the triumph of capitalism, however definitive this triumph turns out to be (Jameson, 2006). In its critique of modernity, and of the idea of progressive enlightenment, postmodernism's failure to adequately distinguish between reason in the service of the commonweal, and reason in the service of sectional interests, has a tendency to conflate modernity with capitalism, and hence to visit the inadequacies of the latter on the former (Malik, 2006).

The postmodern emphasis on the local and the unique elides the totalising materiality of capitalist social relations, whose class-based structures and practices now operate on a global scale (Harvey in Palmer, 2006; Palmer, 2006). It also conveniently overlooks the fact that an individual human right, such as freedom of expression, for example, exists only to the extent that it is universalised and essentialised, that within a given geo-political area it is not arbitrarily suppressed or denied, wherever in the world this may be (Ahmad, 2006). Finally, regarding materiality and our representations of it, as we shall see, it is my contention that we cannot simply construct the world, and our place in it, as we would like them to be.

For these reasons, it is my contention that the postmodern position in this respect offers a default symbolic endorsement 
of late capitalism's highly 'disorganised' and mobile globalism, and is deeply conservative. It is so because it negates the very analytical tools capable of confronting dominatory and exploitative structures and practices where they exist, placing them beyond the critical gaze. As such, following philosopher Jacques Derrida, I want to argue for a reengagement with the spirit of Marx, for a 'hauntology' of his work (Derrida in Sim, 2000). I also want to argue, in opposition to the claim that humanity is at the very pinnacle of its potential, following Eagleton (2006), that genuine progress in reducing inequality will signal the beginning, rather than the (postmodernist) end, of human history.

In what follows, using theoretical, empirical, quantitative and qualitative data, and based on an explanatory critique (Bhaskar, 1998), I will establish the actuality of social class in Ireland, and contrast this with representations of such in the contemporary Irish print media. Given that most information is communicated symbolically, rather than somatically, and the central role of both information and knowledge in the shaping of practice, as we shall see, accuracy is, I contend, essential in order for individuals, and collectives, to decide which social structures they wish to reproduce, and which they wish to transform.

In the section 'Theoretical orientations', I briefly outline my theoretical approach. In 'Theorising social class', I refer to strands of international class-based theory and research. In 'Social class in Ireland', I focus on strands of Irish class-based research. These accounts are short sketches, for reasons of word space, and I include only those details which I consider the most appropriate. In 'Mystifications', I offer examples of previous mystifications of social class in Ireland, and I introduce, and critically comment on, four texts dealing with social class issues in the contemporary Irish print media. Finally, I summarise and conclude.

\section{Theoretical Orientations}

Human social practice is a complex interaction between the subjective and the objective, involving purposive causal activity through which we shape and reshape our environments, which in turn shape and reshape us. All social practice is productive, and by virtue of its type, occupies a specific position in the socio-economic structure, and hence is positioned-practice. Relations between relatively enduring positioned-practices constitute social relations, and the product of all social relations is society (Bhaskar, 1998). However, as a consequence of the capitalist separation of ownership of productive resources from the labour power utilised in their consumption, social relations are not indiscriminate or random, but tiered and ranked, such that they are graded and ordered horizontally and vertically along class and occupational lines.

All social practice is reflexive, and, as a consequence, semiosis is always a significant constituent factor, and, depending on the type of practice concerned, is differentially combined with the practice's material resources (Chouliaraki and Fairclough, 1999). Material resources include the social structures and institutional rituals involved in the practice, such as employer/employee relations, while semiotic resources include the knowledge brought to bear on practice by agents. The former function to constrain the latter, such that we cannot simply construct the world, and our place in it, as we would like them to be. Such that we cannot, for example, confuse the coal miner at the coal face deep underground with the rentier who lives of income from stocks and shares they own in the mine.

Knowledge in this respect is the product of an on-going process of investigation and study, normative for a time until superseded by an understanding more compatible with the world as it exists independently of us. Accurate information is a unit of such knowledge. However, and crucially, agents' understanding of their activities may, through inaccurate information, be subject to mystification, and hence correction, such that they may believe they are doing or witnessing one thing, when in fact they may be doing or witnessing quite another (Bhaskar, 1998).

When I use the term mystification, I refer to inaccurate information. For example, sociologist Pierre Bourdieu considers the concept of meritocracy to be a mystification, and likens the idea to that of the roulette table, an 'imaginary universe', where with each spin of the wheel anything is possible, and anyone can become anything. He contrasts this with the 'constraints' inscribed in social structures and practices which persist over time, such that anyone cannot become anything, and anything is not possible (Bourdieu, 2016).

When I refer to tendencies, I imply causal forces operating in the 'open system' of the social, as opposed to the 'closed system' of a laboratory. In society, structural tendencies, such as social class, as the focus of this study, but others also, including gender and ethnicity, operate among other tendencies, because control and isolation are not an option, as in the laboratory. They may operate realised and acknowledged, or unrealised and unacknowledged, that is, their causality is checked by countervailing tendencies, for instance. Or they may operate realised but unacknowledged, either because masked by other tendencies, or because their causality is incorrectly ascribed to that of others.

\section{Theorising Social Class}

During the production of the goods and services needed for human survival and well-being, the producers enter into specific class-based social relations. As I have alluded to above, this is so because, characteristically, social relations in 
capitalist societies are marked by property relations, and the separation of employers from employees, of capital from labour power. In the private sector, a productive property or capital-owning employer class stand opposed to a capital or productive property-less waged or salaried employee class. In the public sector, the capitalist State takes the role of an employer, replete with its productive assets and capital, and maintains similar relationships with its employees, waged or salaried.

The social relations concerned are characteristically dominatory and exploitative because their interests are antagonistic, with the employers' expanding at the expense of the employees' through their appropriation of the surplus product (Picketty, 2014; Marx, 2016). Also, the common interests of the waged or salaried class in maximising returns of surplus to labour are frustrated by a contrived and hierarchically stratified division of labour within the class itself. While all are either waged or salaried, their homogeneity is undermined by strata, such as managers and technicians, for example, who are instrumentally allied to, and who promote the interests of, capital, as we shall see.

In addition, as the philosopher of history Walter Benjamin observes, while such social relations are material in the first instance, over time they give rise to an overlaid and differential allocation of refined non-material things, again in favour of capital, and at the expense of labour, as we shall see also (Wright, 1997; Benjamin in Eagleton, 2011).

There are, of course, social classes intermediate to, and other than, the two characteristic and enduring classes described above. Those who have productive capital assets, but who do not employ labour, those who draw a wage or a salary, but who are not contracted to an employer, and the unemployed living on the 'crumbs' of society, for example. However, as a consequence of the competitive pressures of capitalist production and accumulation, these classes have a tendency to transience, and to be assimilated into one of the two characteristic classes over time and economic cycles (Marx, 2016; Ollman, 2016).

In the US, Wright (1997) has argued that class is pervasive in contemporary life, a key determinant of life chances. He formulates a position consistent with Marxist class theory in which he defines the structural properties of classes; they are relational, relations are antagonistic, antagonisms are rooted in exploitation, and exploitation occurs in production.

He is particularly concerned to account for the 'embarrassment' and apparent contradiction of productive agents, such as managers and technicians, who, while belonging to the capital or productive property-less waged or salaried class, nevertheless serve capital's interests. He does so by dividing productive capital assets into three types, material, organisational, and intellectual, synonymous with employers, managers, and technicians, respectively. Subsequently, by extending the scope of class-based antagonisms to include acts of domination, he argues that managers and technicians in performing such dominatory acts, and to the extent that they facilitate the appropriation of the surplus of the labour of others, are exploitative in kind (Wright, 1997).

In the UK, the 'Great British Class Survey' (Savage et al, 2015), draws on Pierre Bourdieu's model of social class as comprising three distinct types of capital; economic, cultural, and social capital, referring to income and wealth, interests and activities, and networks and associations, respectively. The authors acknowledge the importance of economic capital in shaping social class relations, but claim that an exclusive focus on such misses class markers which the three types of capital complementing each other can identify. That the three together can furnish a more sophisticated and refined picture of the wider political and cultural significance of social class.

They identify 'elite' and 'precariat' classes at the poles of the class structure. Among the elite they distinguish a strong sense of entitlement for themselves, and of just deserts for the precariat, who the former see as the authors of their own misfortune. Significantly, they also claim that most people remain firmly in the social class into which they are born, and, as a consequence, that notions of meritocracy, equal opportunity, and social mobility, are largely mystifications (Savage et al, 2015).

It is clear that this notion of just deserts allows for the impoverished conditions accruing as a result of capital's structured and class-based demand for low-wage and insecure labour to be ascribed to the fecklessness of the poor themselves. It is also clear that the notion of entitlement allows for the flattering conditions of the elite to be ascribed exclusively to their personal integrity and hard work. This in spite of all the evidence identifying a strong tendency for capital to be largely inherited, and indicating that while examples of the 'self-made' entrepreneur exist, they are rare, and very much the exception (O’Toole, 2010; Chang, 2011; Picketty, 2014; Klein, 2015; Savage et al, 2015).

The evidence also indicates widespread social segregation between the classes. One hundred years ago in the 'big houses', contrary to contemporary mystifications, such as the popular TV series 'Downton Abbey', for instance, great efforts were made to keep servants out of the sight of their employers. They were 'invisible' only for their labour, performed mostly when the employing family was asleep, or out of the house (Hyams, 2011). In the present period little has changed. Class-based social segregation remains pervasive, with separate schools, separate housing, and indeed separate sporting and leisure activities persisting and proliferating, such that the distinct social classes seldom, if ever 
come into contact with each other (Dorling, 2014; McWilliams, 2015).

Finally, in relation to the notion of an elite class at the apex of society, both Dorling (2014) and Picketty (2014) argue persuasively for their status as a 'dominant' or 'ruling' class. Although not homogenous in form in many respects, through their hegemonic cross-ownership and control of productive assets and other forms of capital, the elite are able to strongly influence political, social, and cultural structures and practices on a national and international scale.

\section{Social Class in Ireland}

Much of the research on social class in Ireland adopts a 'Weberian' position, as opposed to a Marxist position, so-called after the sociologist Max Weber, and has a tendency to conflate social class with occupational strata, as we shall see in this section. It uses the former when actually referring to the latter, and understands inequality as an inability to move through such socio-economic strata. Thus, in his conceptualisation of social class, Weber emphasises factors in addition to property relations, interests of a given 'type', between skilled and non-skilled labour, and that of 'status', between white and blue collar labour, for example (Tovey and Share, 2003). This slippage of meaning does not embody concepts of domination or exploitation. Nevertheless, such occupational strata are central to the class schema I have described above, and are relevant here as indicators of the enduring social cleavages associated with the capitalist division of labour, and the differential rewards resulting therefrom.

According to the research, 'rigid' class distinctions are central to Irish life; from the foundation of the State, and indeed before, they are blatant and glaring (Ferriter, 2005; Convery, 2013a). They are palpable during the Dublin Lock-Out, an intense industrial dispute, August 1913 to March 1914, with Dublin a low-wage 'slum' city, very profitable for capital, with the highest mortality rate of all UK cities (McCabe, 2013). They are evident at the birth of the State, between 1919 and 1923, a period of intense working-class activism (Convery, 2013b; Devoy-McAuliffe, 2013). They are evident from July to October 1934, with Dublin a city virtually without a press, following strikes over issues of pay, the length of the working week, and holiday entitlements (Fallon, 2013). They are evident in the institutional incarceration of those with dissenting philosophies, at odds with the 'classless' hegemony of Church and State, with Ireland interning more people in this manner as a proportion of its population than the much maligned USSR in the mid-twentieth century (Convery, 2013a; RTE, 2013a). They are evident also late into the twentieth century in the committal of the children of the poor to industrial schools and convents, well known as places of neglect, abuse, and ill-health (Buckley, 2013).

\subsection{Health}

Social inequality and class in Ireland is strongly registered in its correlation with health, both physical and mental. Research throughout the closing decades of the twentieth century consistently shows that the lower the class the poorer the health. Indeed, across the island as a whole, the vast majority of causes of death occur at a higher rate in the lowest as opposed to the highest social class, and in many cases the variations are 'startling' (Balanda and Wilde in Tovey and Share, 2003). While in the contemporary period, in terms of health improving or declining as one goes up or down the social class 'ladder', as it were, there is a clear social gradient, in that both mortality and morbidity rates are higher in the lower social class groups (O'Toole, 2010). Indeed, across the island as a whole, mortality rates are one hundred to two hundred per cent higher in the lowest occupational class than in the highest for almost all causes (Battel-Kirk and Purdey in O'Toole, 2010).

\subsection{Education}

Social distinctions based on landed and agricultural capital decline as a tendency to structure Irish society over the course of the twentieth century with the growth of industrial and financial capital, and with the expansion of the State (Ferriter, 2005). Conversely, education increases in importance as a tendency to procure well-paid and secure employment. This scenario brings about structural social mobility, that is, mass movement from the blue collar and farm labourer class into the pre-existing white-collar class.

Research from the end of the twentieth century, however, indicates that the latter benefit disproportionately from educational expansion. Indeed, in terms of participation rates, the more advanced the education, the greater the disparities, with the children of manual workers and/or farm labourers constituting a tiny proportion of third-level university entrants (Jackson, 1990; McCullagh, 1990; Drudy and Lynch, 1993). From around the same time, research shows relative social mobility, that is, movement through the occupational structure aside from any large scale structural changes, to be low among the lower classes, and that this situation is enduring (Breen and Whelan, 1996; Tovey and Share, 2003).

In the contemporary period, in terms of third-level education, the participation rates of the children of higher professionals are at saturation point, and have been for years, with those of the children of semi-skilled and unskilled workers remaining a fraction of this (O'Toole, 2010). Thus, despite investment in education over the decades, patterns of inequality have remained largely undiminished, and, if anything, have been reinforced, such that the relative advantage associated with class persists (Clancy, 2001; Tovey and Share, 2003). 


\section{Mystifications}

At this point, prior to my textual commentaries, as cultural contextualisation, I want to briefly exemplify the use of mystification in the confounding of issues of social class in Ireland. This has involved, for instance, a Limerick courtroom's ruling that class distinctions between farm owners and farm labourers do not exist. Dublin's Abbey Theatre refusing to host the play 'Whistle in the Dark', by Tom Murphy, because the 'dispossessed class' which it refers to, likewise, does not exist (Ferriter, 2005). It has involved national newspapers, such as the Irish Times, and the Irish Independent, promoting a picture of Ireland as a classless idyll. It has also involved the use of the amorphous and catch-all term 'coping classes' in the print media to blur deep social distinctions based on hierarchically ordered socio-economic structures and practices (Cullinane, 2013; Pierse, 2013).

Similar tendencies are implied in the dearth of emphasis on the class-based works of lauded poets and playwrights, such as W.B. Yeats and Sean O'Casey; the former's apparent 'contempt' for waged or salaried workers is tellingly sidestepped, as are the latter's 'socialist' texts (Pierse, 2013). Finally, they are also implied in a recent Sociology of Ireland, which, despite the authors' claim regarding the primacy of social locations in shaping agents' social practice, omits any chapter dedicated to social class in a section given over to social divisions (Share, Corcoran, and Conway, 2012).

\subsection{Notes on Textual Commentaries}

The textual commentaries here are purposefully cross-sectional rather than longitudinal in kind, marking a specific time in Irish society, and were chosen at random from newspapers across the range for such. They do not follow a formal methodical approach, but are the product of an informal, unobtrusive, and iterative process, involving close attention to both vocabulary and grammar.

All the texts but Text One, which features the entire original article, constitute the opening paragraphs from the originals, and capture their substance and thrust, as I understand them. The texts have authority and significance in virtue of their institutional status, and warrant critical investigation by virtue of their presenting a particular version of reality to their readers. It is important to stress that these texts are 'hard' news items, and not editorials or opinion columns, and that the actualities presented could have been presented differently, as compilers have many options available to them in terms of lexico-grammar (Halliday, 2004).

The term 'relational process' refers to the grammatical use of a form of the present tense to assert a judgement as factual; in the clause 'Summer is a lovely time', for example, 'is' functions as a relational process. When I refer to modal auxiliaries, such as 'would', 'will', 'might', 'could', and 'would', among others, I do so because while expressing judgement and degrees of possibility, they can confer a sense of inevitability, such as in the sentence 'It will be warm today', for example.

A 'passive voice' statement is one which allows for the removal of any reference to agency, or to the source of a judgement. For example, the clause 'The critic likens the film to a classic' is in the active voice, as opposed to 'The film is likened to a classic' in the passive voice.

Nominalisation involves the substitution of a noun or noun phrase for a process. For example, nominals 'the economy' and 'the recovery' represent nominalisations, such that the complex social practices and relations concerned are elided.

A superordinate functions collectively, such that it may conceal divisions and conflicts of interest. For instance, in the clause 'The legislature is small in Ireland', the superordinate nominal 'legislature' masks the hierarchies and tensions involved both within and between political groups.

In terms of productive assets, and forms of capital, that is, material, organisational, and intellectual productive assets, and economic, cultural, and social capital, I highlight their existence where relevant, but I do not refer to assets or capital not directly implied by the text itself.

It is significant that all of the texts function as tendencies to promote specific interests, the interests concerned are exclusively those of the dominant parties, and that none acknowledge either that they are so doing, or indeed the class-based nature of the practices themselves.

All the texts are declarative in mood, and each is prefaced with a short situational contextualisation. The commentaries are not intended to be exhaustive, including only those elements which I consider significant, and for reasons of word space, are kept to a minimum. 


\subsection{Textual commentaries}

\section{Text One}

\section{The Irish Daily Mirror 16 September 2015.}

National politicians are 'starkly' unrepresentative of the population as a whole, that is, over-representative of the professional stratum, and under-representative of the manual working stratum in the capitalist division of labour (O’Toole, 2010).

Prefabs plan could tackle homes crisis.

PREFAB homes could help ease the homeless crisis, it has emerged.

Two-bedroom units went on display in Dublin yesterday and could be used as a short-term solution.

Environment Minister Alan Kelly said they could last for up to 70 years.

He added: 'The quality is excellent. The lifespan of some of these units is 60 to 70 years guaranteed.

'These aren't cheap. They range from E75,000 to E100,000 a unit.

'But what it does is it allows us to develop homes quicker.

'We're only going to put people in here for a certain amount of time until we have a more long-term solution'. (p14)

This text, while tacitly acknowledging the limitations of prefabs, nonetheless constitutes a defence of their use as a remedy for the growing homelessness crisis in Ireland. In so doing, it empowers the Minister, and hence the State, while disempowering the homeless. It implies social capital, in that politicians have access to wide networks of contacts by virtue of being legislators. It is also significant in that it implies a precariat who rely on the State for housing provision.

The dubiousness of the plan is implied in the phrase 'a more long-term solution', line 8, an anaphoric reference to that of 'a short-term solution', line 3, which it affirms. It is implied also in the phrase 'a certain amount of time', line 8, in which the modifier 'certain' signals an unspecified temporality, such that the political decision-makers, as agents in this text, are themselves unsure of the time-scales involved.

However, the use of the nominal 'homes' throughout, rather than 'houses', for example, implies intimacy, and represents a tendency to negate the pejorative implications of prefab. The nominal 'on display', line 3, connotes something worth seeing, and that of 'unit(s)', repeated in lines 3, 5, and 6, a self-contained and completeness. In a similar manner, the nominal 'lifespan', line 5, as an anthropomorphism, assigns a vital human characteristic to the prefab, connoting a further sense of intimacy. All have a tendency to commend the prefab for the purpose at hand.

The present perfect 'it has emerged', line 2, allows for the content of its report, which is supportive of the prefab, to go unattributed, rather than to its source, Minister Alan Kelly, thereby conferring a false sense of impartiality to it. The clauses 'The quality is excellent' and 'These aren't cheap', lines 5 and 6, respectively, are relational processes which, while registering opinions, factually equate the prefab with good taste and good value. In addition, all four uses of the modal auxiliary 'could', lines 1,2,3, and 4, imply both the availability and suitability of the prefab for the purpose.

Finally, and specifically in terms of agency, all the personal pronouns 'We're', 'us', and 'we', lines 7 and 8 , operate exclusively, and imply a practice enacted by politicians on others. Indeed, the clause 'But what it does...', line 7, with pronoun 'it' substituting for the process of allocating homeless people to prefabs, represents a cataphoric reference to the following clause complex, in which agency is denied the homeless, who are simply acted upon.

\section{Text Two}

\section{The Irish Times 23 October 2015.}

Irish Rail (Iarnrod Eireann) are the national State-owned rail carrier. The First Class seating arrangements which they provide do not map directly onto wider societal class structures. They are significant, however, because of the implication, fully endorsed by the State, that segregation in public spaces is normative. Siptu and NBRU are the trade unions involved.

Irish rail says drivers offered $8 \%$.

Talks were continuing late last night to avert a threatened strike that will bring rail services nationwide to a halt this morning.

Management at Iarnrod Eireann maintained that productivity proposals under discussion would see the earnings of train drivers increase by nearly 8 per cent over three years.

Siptu and the NBRU said it was 'manifestly untrue' to say a position had been reached where productivity 
measures could be delivered which would generate a rise in earnings. The dispute centres on claims by drivers for payment for past productivity. The company has said it would share the benefits of future productivity with drivers.

It is understood company proposals centre on introducing more efficient rosters which would see drivers operate trains more frequently within existing shift arrangements. This would be aimed at generating savings which could be used to fund additional payments to drivers...(p1)

This text is significant because in its dealing with opposing class-based interests, it implicitly promotes the State's position, through the defence of its management, with the use of linguistic devices such as euphemism, modality, nominalisation, and the passive voice. In so doing, it implies organisational productive assets synonymous with management in their capacity as decision-makers.

The issue of productivity is central to this text, and features in all paragraphs, except the opening paragraph, in which it is presumed. The nominal groups 'productivity proposals', line 4, 'productivity measures', lines $6-7$, 'past productivity', line 8, and 'future productivity', line 8, all signal an increased workload on drivers.

The nominalisation 'Talks', line 2, abstracts from the social relations between the two parties to the dispute; it does not apportion unreasonableness to either, and, as such, implies impartiality. However, and on the contrary, the perlocutionary effect of the combination of the claim that management have offered a pay rise, line 1, the modified nominal 'threatened strike', line 2, and modalised process 'will bring rail services nationwide to a halt this morning', lines $2-3$, is to connote a sense of culpability on drivers. The modified nominal 'late last night', line 2 , furthermore implies a sense of drivers having to be tirelessly placated.

The modalised process 'would see', line 4, clearly registers management's claim of the possibility of benefits to drivers of their productivity proposals. However, the elision of the drivers in the passive voice modalised process 'could be delivered [by drivers]...', line 7, denies drivers a voice, and, as such, a response, in the context of their denial of such possibilities being precisely the issue at hand. The modalised process 'would share the benefits of future productivity', line 8, registers management's intention to give to drivers only a fraction of the product of their labour in the event of future productivity, and is euphemistic because it presents an act of exploitation as if it were an act of generosity.

The passive voice 'It is understood', line 10, allows the compiler to put management's position while concealing that this is so. In effect, the modalised processes 'would see', 'would be aimed at', and 'could be used', lines 10 - 12, allow for demands, such as increased productivity, and intentions, such as to partly withhold any additional value produced, to be expressed as possibilities, thereby moderating their force.

\section{Text Three}

\section{The Irish Daily Mail 20 November 2015.}

This text reflects the operation of a 'Golden Circle', both in the public and private spheres, who are well-rewarded for their services to capital, with twenty-one bankers in Ireland earning over one million euros in 2011, a time of deep austerity for many (O'Toole, 2010; RTE, 2013b).

Central Bank to 'keep retention pay in place'

The Central Bank says it intends to continue giving 'retention payments' to middle management - after it emerged the bank has paid secret top-ups of around $21 \%$, to 30 members of its staff.

The bank said that the payments are used as an 'incentive' to keep 'skilled' staff in their jobs and to stop them leaving

It was claimed that those in receipt of the payments were in 'middle management' and earning salaries ranging from $\mathrm{E} 67,000$ to $\mathrm{E} 84,000$.

'We are not talking about huge salaries,' a Central Bank spokeswoman told the Irish Daily Mail.

In a statement released yesterday, the Central Bank also said it had met with representatives from the Unite trade union in May of this year to brief them on the retention policy, and had provided them with more details and numbers since then.

Unite, which is the main trade union for Central Bank staff, is seeking legal advice over the confidential payments of more than E20,000...(p16)

This text is significant because it mystifies the conflict of interests between management, and non-management in the Central Bank as State employees, but nevertheless defends the former. As such, it implies organisational productive assets. 
In lines 2 and 6, and lines 3 and 4, respectively, the modified nominal 'middle management' and nominal 'staff' are used synonymously. However, and on the contrary, the nominal 'staff', line 12, is also used to designate non-managerial workers. In this way, their opposing interests are confounded, and both are defined according to the same criteria. The use of the superordinate nominals 'Central Bank' and 'bank' throughout functions to mask the hierarchical division of labour within the bank, and the fact that it is managers who are secretly paying other managers.

The quotation 'We are not talking about huge salaries', line 8 , is marked by informality, and the use of the nominal group 'Irish Daily Mail', also line 8, functions to personalise the message, directly implicating the reader as reader of the Irish Daily Mail. The perlocutionary effect, as in a conversation between friends, is to invite the reader to sympathise with the contents. Additionally, the personal pronoun 'We' functions inclusively, reinforcing this intimacy, and, as a whole, the clause complex constitutes a tendency to mitigate the inequity of such payments, against a backdrop of severe pay cuts for many across the public sector at this time.

The purpose of the infinitives 'to keep', and 'to stop', line 4, is to stress the necessity of the payments - there was and is no choice but to make them - and they operate tautologically, such that the sentiment is repeated, double stressing its justificatory rationale.

The significance of the simple past tense process 'it emerged', line 2 , and passive voice 'It was claimed', line 6 , is that they remove any reference to the original source of the claims regarding the payments, thereby masking the fact that the bank only acknowledged them after they were challenged on the issue in the media via the trade union. They function to deflect criticism from the bank.

\section{Text Four}

\section{The Irish Independent 2 February 2016.}

It has been claimed by the State in the aftermath of the economic crisis beginning in 2008, that a deficit of expertise, such as business acumen, in the Department of Finance was responsible. To the extent that this promotes particular class interests, and masks the crisis-prone nature of the capitalist system itself, it registers the State's class bias (Allen and O’Boyle, 2013). The Dail is the Irish parliament.

Business chiefs warn 'political instability' will place jobs at risk.

Exclusive.

Pre-election letter says the economy is at a 'critical point'.

JOBS will be lost if the result of the General Election leads to 'political instability' or gives a greater sway to fringe elements, the country's top business leaders have warned in a letter to the Irish Independent.

Executives working with a range of national and international companies have joined forces to ask voters to look at the global economic situation.

With polls suggesting the country could be heading for a hung Dail, they warn: 'Ireland needs a stable government capable of making the right policy choices for the future'. In the letter, the senior business people write that the recovery is at a 'critical point'.

They caution against handing 'greater influence to populist left political parties and fringe elements that are anti-business and anti-job creation'...(p1)

This text constructs a dualism between business, which it normalises, and leftist politics, which it problematises. It is not clear whether the business people concerned are owners of productive resources and capital, or salaried senior managers. In the former scenario, economic, cultural, and social capital, and material productive assets are all implied, as is their status as an elite, dominant, or ruling class. In the latter, cultural, and social capital, and organisational productive assets are implied.

The verbal processes 'warn', line 1, 'have warned', line 5, and 'warn', line 8 , all imply a threat, as does the process 'caution', line 11, intensified with the use of the modified nominal 'critical point', repeated in lines 3 and 10. Indeed, similar alerts feature throughout, registered by modified nominals 'top business leaders', line 5, and 'senior business people', line 9, nominals 'chiefs', and 'Executives', lines 1 and 6 (and by pronouns 'they', line 8, and 'They', line 11). These labels imply competence, and hence credibility, a credibility which is extended across space and time by the phrase 'a range of national and international companies', line 6.

The source of the threat is 'political instability', repeated in line 1, and line 4, synonymous with the political left, repeated in line 5, and line 11, with the modifier 'fringe' functioning as a spatial metaphor to signal their distance from the complex issues concerned. Indeed, the significance of the modified nominal 'populist left', line 11, is that it conflates the left with the uninitiated majority who lack the expertise to manage the economy. This is given more 
resonance in lines $6-7$; the implication of the exhortation by business executives to voters 'to look at the global economic situation' is that they have, are conversant with it, and are the ones qualified for the task ahead.

The clauses 'the economy is at a critical point', line 3, and 'that are anti-business and anti-job creation', lines $11-12$, are relational processes, and function to construct the opinions of business leaders as if they were factual. The modalised processes 'will place jobs at risk', line 1, and 'JOBS will be lost', line 4, while also expressing opinions, function to assert these opinions as inevitabilities. The upper case adds stress to the sentiments.

Finally, nominals such as 'the country's', line 5, and 'the country', and 'Ireland', line 8, are superordinates, which function to denote a common interest, rather than the characteristic class-based interests which prevail.

\section{Summary and Conclusion}

In this study, I argue that inequality is intrinsic to capitalism, and that an effective way in which to confront such socio-economic cleavages, contrary to the postmodern position, is through class-based critical analysis.

I explain that all social practice is purposive causal activity through which we shape and reshape our environments, which in turn shape and reshape us, and that semiosis is always a significant factor in practice, but is constrained by materiality, such that we cannot simply construct the world and our pace in it as we would like them to be.

I explain the class-based nature of capitalist societies, and engage with research from the US, which, through its identification of different types of productive assets, establishes both the persistence of social class, and its centrality in determining life chances. I engage with research from the UK, which, through its emphasis on distinct types of capital, also confirms the on-going significance of social class in shaping opportunities in life. I cite claims from across the developed economies establishing that, for most, notions of social mobility, equal opportunity, and meritocracy are mystifications, and I offer evidence indicating widespread and enduring social segregation along class-based lines. I also invoke research from across the developed economies, which confirms the existence of a 'dominant' or 'ruling' class, in terms of their shaping of national and international political, social, and cultural structures and practices.

In the specifically Irish context, I argue that blatant and glaring class-based distinctions are central to Irish life, both prior to and since independence, although over the years mystified in various ways. That deep cleavages in health care outcomes persist between the social strata, and despite educational advances in the twentieth century, that the research clearly shows patterns of inequality remain undiminished in the present era, with socio-economic origins continuing to map strongly onto socio-economic destinations.

Regarding my commentaries, I establish that the texts represent tendencies to mystify the actuality of social class because all promote specific class interests, interests which are exclusively those of the dominant parties, but that this is not acknowledged, nor indeed is the class-based nature of the practices concerned. Thus, they function to empower the State while denying agency to the precariat, to promote capital's position over workers in an industrial dispute. To confound conflicts of interests in the public sector in favour of capital and at the expense of labour, and to contrive a dualism between business elites and leftist politics, attributing desirability, and undesirability to them, respectively.

In conclusion, it is clear from the foregoing that if we are to seriously confront inequality, both within and across national boundaries, we have to challenge capitalism as a class-based socio-economic system, and its inherently unequal social relations. However, postmodern mystifications reject the notions of social class, Marxist critique, and indeed capitalism itself, as essentialisms, such that the distortions I have identified above do not register on the postmodernist scale. Through this default symbolic endorsement of late capitalism's highly 'disorganised' and mobile globalism, what we have is a conservative deference to the dictates of capital, which is given effective immunity from any critical gaze.

To accurately inform agents and collectives is to empower them, such that, if they so wish, they can transform, rather than simply reproduce, inequitable social and institutional structures, through changing their practices accordingly. It also enables them, if they so wish, to produce and reproduce structures and practices synonymous with a state of genuine equality, such as that envisaged by Karl Marx in his vision of the 'realm of freedom', wherein each contributes according to their ability, and receives according to their needs.

This is why it is important to challenge all mystifications, whether postmodern, print media, or otherwise, because if we do not tendencies to produce and reproduce inequality simply pass us by, operating realised but unacknowledged. Indeed, critical social scientists are obliged in terms of knowledge interests to do so. This short study, in challenging such tendencies, and in highlighting the emptiness of notions of 'classlessness' in Ireland is, I hope, a modest contribution to such. 


\section{References}

Ahmad, A. (2006). Culture, nationalism, and the role of intellectuals. In E. M. Wood and J. B. Foster (eds) In defense of history. Marxism and the postmodern agenda, 51-64. Delhi: Aakar.

Allen, K., \& O’Boyle, B. (2013). Austerity Ireland. The failure of Irish capitalism. London: Pluto Press.

Balanda, K. P., \& Wilde, J. (2001). Inequalities in Mortality 1989-1998: A Report on All-Ireland Mortality Data. Dublin: Institute of Public Health in Ireland.

Battel-Kirk, B., \& Purdey, J. (2007). Health Inequalities on the Island of Ireland: The Facts, the Causes and the Remedies. Dublin: Public Health Alliance of Ireland.

Benjamin, W. (1999). Illuminations. London: Pimlico.

Bhaskar, R. (1998). The possibility of naturalism. A philosophical critique of the contemporary human sciences. London: Routledge.

Bourdieu, P. (2016). The forms of capital. Available at www.marxists.org/reference/subject/philosophy/works/fr/bourdieu-forms.capital.htm

Breen, R., \& Whelan, C. (1996). Social mobility and class in Ireland. Dublin: Gill and Macmillan.

Buckley, S. A. (2013). The problem is one not of criminal tendencies, but of poverty: the NSPCC, John Byrne and the industrial school system in Ireland. In D. Convery (ed) Locked-out. A century of Irish working-class life, 109-203. Sallins: Irish Academic Press.

Byanyima, W. (2015). Inequality and climate change: 2015 's challenges. Available at www.weforum.org/agenda/2015/01/inequality-and-climate-change-twin-challenges-of-2015/

Chang, H. J. (2011). 23 Things they don't tell you about capitalism. London: Penguin

Chouliaraki, L., \& Fairclough, N. (1999). Discourse in late modernity. Rethinking critical discourse analysis. Edinburgh: Edinburgh University Press.

Clancy, P. (2001). College entry in focus: a fourth national survey of access to higher education. Dublin: Higher Education Authority.

Convery, D. (2013a). Introduction. In D. Convery (ed) Locked-out. A century of Irish working-class life, 1-7. Sallins: Irish Academic Press.

Convery, D. (2013b). Uniting the working class: history, memory, and 1913. In D. Convery (ed) Locked-out. A century of Irish working-class life, 23-38. Sallins: Irish Academic Press.

Cullinane, L. (2013). As if you were something under their shoe: class, gender and status among Cork textile workers, 1930-70. In D. Convery (ed) Locked-out. A century of Irish working-class life, 175-191. Sallins: Irish Academic Press.

Derrida, J. (1994). Specters of Marx: The State of the Debt, the Work of Mourning, and the New International. Tr. P. Kamuf. London: Routledge.

Devoy-McAuliffe, F. (2013). Workers show their strength: the 1918 conscription crisis. In D. Convery (ed) Locked-out. A century of Irish working-class life, 75-91. Sallins: Irish Academic Press.

Dorling, D. (2014). Inequality and the 1\%. London: Verso.

Drudy, S., \& Lynch, K. (1993). Schools and society in Ireland. Dublin: Gill and Macmillan.

Eagleton, T. (2006). Where do postmodernists come from? In E. M. Wood and J. B. Foster (eds) In defense of history. Marxism and the postmodern agenda, 17-25. Delhi: Aakar.

Eagleton, T. (2011). Why Marx was right. London: Yale University Press.

Fallon, D. (2013). Newsboys and the animal gang in 1930's Dublin. In D. Convery (ed) Locked-out. A century of Irish working-class life, 93-108. Sallins: Irish Academic Press.

Ferriter, D. (2005). The transformation of Ireland 1900 - 2000. London: Profile Books.

Fukuyama, F. (1992). The End of History and the Last Man. London; Hamish Hamilton.

Halliday, M. A. K. (2004). An introduction to functional grammar. $3^{\text {rd }}$ Ed. London: Edward Arnold.

Harvey, D. (1990). The Condition of Postmodernity: An Enquiry into the Origins of Cultural Change. Oxford: Basil Blackwell. 
Hyams, J. (2011). The real Downton Abbey: how life was really lived in stately homes a century ago. London: John Blake.

Jackson, P. (1990). Worlds apart - social dimensions of sex roles. In P. Clancy., S. Drudy., K. Lynch., and L. O’Dowd (eds) Ireland: a sociological profile, 287-306. Dublin: Institute of Public Administration/The Sociological Association of Ireland.

Jameson, F. (2006). Five Theses on Actually Existing Marxism. In E. M. Wood and J. B. Foster (eds) In defense of history. Marxism and the postmodern agenda, 175-183. Delhi: Aakar.

Klein, N. (2015). This changes everything. Capitalism vs. the climate. London: Penguin.

Malik, K. (2006). The mirror of race: postmodernism and the celebration of difference. In E. M. Wood and J. B. Foster (eds) In defense of history. Marxism and the postmodern agenda, 112 - 133. Delhi: Aakar.

Marx, K. (2016). Capital. A critique of political economy. Volume One. Available at www.marxists.org/archive/marx/works/1867-c1/

McCabe, C. (2013). Your only God is profit: Irish class relations and the 1913 lockout. In D. Convery (ed) Locked-out. A century of Irish working-class life, 9 - 21. Sallins: Irish Academic Press.

McCullagh, C. (1990). Deviance and crime in the Republic of Ireland. In P. Clancy., S. Drudy., K. Lynch., and L. O’Dowd (eds) Ireland: a sociological profile, 344-361. Dublin: Institute of Public Administration/The Sociological Association of Ireland.

McWilliams, D. (2015). Ireland's great wealth divide. RTE One. $21^{\text {st }}$ September. $21,35$.

Nanda, M. (2006). Against social de(con)struction of science: cautionary tales from the Third World. In E. M. Wood and J. B. Foster (eds) In defense of history. Marxism and the postmodern agenda, 74-96. Delhi: Aakar.

O’Toole, F. (2010). Enough is enough. How to build a new republic. London: Faber and Faber.

Ollman, B. (2016). Marx's Use of 'Class'. Available at www.nyu.edu/projects/ollman/docs/class.php

Picketty, T. (2014). Capital in the twenty-first century. Cambridge MA: The Belknap Press/Harvard University Press, Tr. A. Goldhammer. https://doi.org/10.4159/9780674369542

Pierse, M. (2013). From yeatsian nightmares to tallafornian dreams: reflections on classism and culture in 'classless' Ireland. In D. Convery (ed) Locked-out. A century of Irish working-class life, 193-209. Sallins: Irish Academic Press.

RTE. (Radio Telefis Eireann). (2013a). Behind the walls. $6^{\text {th }}$ January. 23.05.

RTE. (Radio Telefis Eireann). (2013b). News now. $15^{\text {th }}$ July.

Savage, M., Cunningham, N., Devine, F., Friedman, S., Laurison, D., McKenzie, L., ... Wakeling, P. (2015). Social class in the $21^{\text {st }}$ century. London: Penguin.

Share, P., Corcoran, M., \& Conway, B. (2012). A sociology of Ireland. $4^{\text {th }}$ Ed. Dublin: Gill and Macmillan.

Sim, S. (2000). Postmodern encounters. Derrida and the end of history. Cambridge: Icon.

Tovey, H., \& Share, P. (2003). A sociology of Ireland. $2^{\text {nd }}$ Ed. Dublin: Gill and Macmillan.

Wood, E. M. (2006). What is the postmodern agenda? In E. M. Wood and J. B. Foster (eds) In defense of history. Marxism and the postmodern agenda, 1-16. Delhi: Aakar.

Wright, E. O. (1997). Classes. London: Verso.

\section{Copyrights}

Copyright for this article is retained by the author(s), with first publication rights granted to the journal.

This is an open-access article distributed under the terms and conditions of the Creative Commons Attribution license which permits unrestricted use, distribution, and reproduction in any medium, provided the original work is properly cited. 